\title{
STRATEGIC ALIGNMENT IN THE BRAZILIAN AUTOMOTIVE CHAIN
}

\author{
Ricardo Silveira Martins \\ UFMG \\ martins@cepead.face.ufmg.br
}

\author{
Osmar Vieira Souza Filho \\ Interdisciplinary Center for Logistics Research and Extension (NIPELOG/UFMG) \\ osmar.br@gmail.com \\ Susana Carla Farias Pereira \\ FGV-EAESP \\ susana.pereira@fgv.br
}

\author{
Luiz Carlos Di Serio \\ FGV-EAESP \\ luiz.diserio@fgv.br
}

\begin{abstract}
The research objective is verifying the strategic alignment of supply practices between automakers and suppliers in the Brazilian automotive supply chains. It makes an exploratory-descriptive study of objectives, using quantitative/qualitative procedures and inductive reasoning. The concept used for analyzing the alignment of practices was based on Vachon et al. (2009). The main conclusion of this study is that suppliers and automakers seem to align their supply strategy, giving support to a desirable situation of single chain project. The subsidiary conclusion is the lack of relationship between intensity of the link and misalignment in these companies. The main contributions are the analysis of the relationship established in tiers that are the furthest removed from the focal companies; identification of practices that support the expansion of a new model of arrangements implemented by automakers in Brazil; and understanding of the processes that companies have adopted in order to manage their supply chains and the implications of these activities for the competitiveness of both the company and the supply chain as a whole.
\end{abstract}

Keywords: Supply practices, supply chain alignment, Brazilian automotive industry

\section{INTRODUCTION}

The paradigm for the development of networks or chains of supply companies in response to a more competitive global market highlighted the need to implement cooperative, collaborative and competitive concepts and practices in inter-company relationship. Experience has shown that the organizations which obtain the best results are precisely those that are most successful in organizing, coordinating and managing relationship with their partners in the network (Christopher, 2005). Thus, the organizations comprising these chains depend on satisfactory performance from all their partners.
In order to reach this level of relationship, the automakers encouraged a gradual process of reduction in the number of suppliers. Reducing the number of points of contact made it possible to establish collaborative relationship with first tier suppliers, thus contributing to the development of both innovative capacity and new products (Di Serio et al., 2005). Once the improvements in the regularity and accuracy of performance required by the automakers had been obtained from suppliers (Barrat and Oliveira, 2001), it was thus possible to establish the proper basis for managing component and systems suppliers and to allow the automakers to maintain minimum inventory levels. 
Spekman et al. (1998) emphasize that the concepts of collaboration, cooperation and integration should be implemented to the most important links within the network. It is in this way that one does not lose sight of the aim of the chain, namely, to satisfy the needs of the end customer. This implies other equally important connections, such as those which take place between buyers and suppliers all across the network.

Chopra and Meindl (2007), Cox (2004) e Cox et al (2007) complement this approach by stressing the fact that the individual strategies of each link in the supply chain must be aligned with the competitive strategies adopted within the whole chain.

This alignment relationship is especially important in the case of the automotive industry in Brazil, one of the world 's most important producers of automobiles $(3,182,923$ units in 2009) and also of parts and components. Brazil has also become a development centre for new products. According to Fischmann (2007), the four automakers with the greatest share of the Brazilian market have already reached the stage of developing complete derivative projects, which is considered to be the penultimate stage in the scale of engineering competence for new-product development.

The primary research objective is verifying the strategic alignment between companies in the Brazilian automotive supply chains. This study analyzes management models used in the supply chains of the Brazilian automotive industry, based on the supply practices adopted by business partners automakers and $1^{\text {st }}$ tier suppliers - with a view to identifying alignments in these practices. For this purpose, a research hypothesis was formulated. The search for this evidence was based on the priority given by companies to performance criteria relating to management of suppliers. Still, it is objective of this study to evaluate the impact that the intensity of the link established between companies produce in the alignment of practices. To analyze that, a second hypothesis was formulated, and responding to it will shed light on the relationship between those two variables.

This article is divided into five sections, including this introduction. The second section presents a revision of the literature on supply chain strategic fit and collaborative relationships in supply chains, plus the research hypothesis. Section 3, presents the research methodology, along with the characteristics of the sample. Section 4, contains the analysis and discussion of the results and, in the final section the main conclusions.

\section{LITERATURE REVIEW}

No single company has all the resources it needs to operate. Therefore, the interaction with other companies is an important way to gain access to necessary resources to operate (Skjoett-Larsen, 1999). The companies provide resources to each other, and for this reason resources are an important factor influencing business relationships (Hakansson and Snehota, 1995; Ford et al, 2003). According to Gadde and Hakannsson (2001), the set of resources is associated with a system-wide resource providers, and a substantial part will be provided by other companies through inter-organizational relationships.

This brief introduction helps to present the idea of managing supply chain relationships as a prerequisite to achieve an adequate position in a competitive environment. In the present section, there will be discussed the importance of managing supply chain relationships and to seek for strategic alignment of practices adopted in supply chains.

\subsection{Supply Chain Relationships}

In recent years supply chain management has grown in importance in the corporate agenda and is cited as a reason for corporate success or failure (Cox, 2004; Cox et al, 2007; Godsell et al, 2010). For the authors, poor availability of products that customers want, and excessive stocks of those they do not - have plagued many companies and created a clash between marketing and other functions. With the role to assist the companies to solve those problems, supply chain management is now seen as a major competitive weapon (Christopher, 2005).

Increasingly, supply chain management is being recognized as the management of key business processes across the network of organizations that comprise the supply chain (Croxton et al, 2001). The authors present the definition of supply chain management proposed by The Global Supply Chain Forum, which comes to be "the integration of key business processes from end user through original suppliers that provides products, services, and information that add value for customers and other stakeholders". The Forum members identified eight key processes that need to be implemented within and across firms in the supply chain. 
One of the eight key-process is supplier relationship management, which is the process that defines how a company interacts with its suppliers. Just as a company needs to develop relationships with its customers, it needs to forge close relationships with a small subset of its suppliers, and maintain more traditional relationships with the others (Croxton et al, 2001).

From the discussion above, it is possible to perceive the increasing importance attributed to the supply management of firms and supply chains. The supply function has nowadays a decisive role to play in the value generation to the final customer. In recent years, several academic and professional papers have been pointing the strategic relevance of the supply practices to leverage the competitive capacity of companies and supply chains (Ogden et al, 2005; Paulraj et al, 2006; Zheng et al, 2007; Gonzalez-Benito, 2010; Ambrose et al, 2010). According to González-Benito (2010), the best performing firms are those that combine quality, dependability, and flexibility as priority objectives and relegate cost reductions to secondary importance. In these cases, purchasing price decreases its relative importance in supply strategies.

Consequently, in order to explain the performance of business, it becomes necessary to understand the supply practices adopted by organizations, which has been perceived as a strategic resource vital to achieve high levels of quality, quick response and cost reduction (Carr and Pearson, 2002). Therefore, the current paradigm of competition is based on the reformulation of the way companies relate, shaped by the competitive environment in which they operate and the understanding of the interdependence between them (Christopher, 2005).

Relationships can be understood as a type of coordination between those firms involved, obtained by means of adaptation (Skjoett-Larsen, 1999). In the author opinion, adaptations are mutual adjustments in activities, products, management systems and production processes, and have to do with the fact that activities can be carried out in a personalized manner in diverse situations while other activities can be carried out in a single way, depending on the buyer with whom they are associated. These adaptations are the crucial ingredient for inter-organizational relationships.

The changes made as a result of a relationship may be carried out by either of the companies involved but both of them will always be affected. They will appear in the course of time as a means of solving problems (Hakansson and Snehota, 1995), of improving performance, even when there is a cost (Gadde and Hakansson, 2001), and as a way of making better use of resources in the context of the supply chain (Skjoett-Larsen, 1999).

Christopher (2005) and Lambert, et al. (1998) hold that the inclusion of the relational approach in Management Science analytical and strategic literature constitutes one of the most significant advances in management thought in recent years.

In this approach, organizations are not only studied according to their organizational form and activities but also by the way in which they interact with suppliers and customers. Ford et al (2003) point out that a closer relationship derives from the recognition that this is the most appropriate way of obtaining access to resources controlled by third parties so that they can be added to its own resources and skills. Moreover, interaction makes it possible to increase coordination of the activities carried out by the group of companies that constitute the relationship, thus eliminating similar activities and increasing the level of complementarity between their organizations.

According to this relational approach, collaboration is a concept which should not only be applied to relationship between close business partners but as processes developed throughout the network (Spekman et al., 1998). In other words, they emphasize the need to integrate functional silos and begin to understand that they are interdependent and dedicated to the aim of satisfying the needs of the end customer (Cousins, 2005). The result of these links is a set of interconnected and interrelated firms that have the common aim of obtaining competitive advantage for the whole network (Dyer and Chu, 2000).

As shown in Figure 1, Monczka et al. (2002) propose a classification system with four distinct phases to show how relationship develop over time. According to this classification, relationships progress from the situation where merely commercial attitudes predominate - Phase 1 and then, under the influence of antagonism, reach a stage where there are a certain number of initiatives for joint activities - Phase 2 . These activities then deepen and bring about the need to come into closer contact, to cooperate, in order to support strategies that are differentiated according to cost and level of service - Phase 3, until they mature to the point where trust and commitment provide sufficient basis for exchange of information and joint planning. This is Phase 4, which in the opinion of these authors characterizes collaboration. 
Figure 1. Development of Relationship

\begin{tabular}{|c|c|c|}
\hline Phase 1 & Antagonism & $\begin{array}{l}\text {-Each party regards the other with a minimum of trust or respect; } \\
\text { - Relationship are frequently hostile; } \\
\text { - Multiple-source Strategy, competitive offers, short-term contracts; } \\
\text { - Suppliers unable to offer price reductions are immediately replaced. }\end{array}$ \\
\hline Phase 2 & $\begin{array}{c}\text { Competitive or } \\
\text { Adversarial }\end{array}$ & $\begin{array}{l}\text { - Only suspicion instead of complete mistrust; } \\
\text { - Multiple-source Strategy, frequent change of sources; } \\
\text { - Beginnings of a close relationship at work. }\end{array}$ \\
\hline Phase 3 & Cooperation & $\begin{array}{c}\text { - Closer relationship due to common aims; } \\
\text {-Recognition of the advantages of a lean supplier base. } \\
\text { - Strategies focused on reductions in the time of the overall cycle. }\end{array}$ \\
\hline Phase 4 & Collaboration & $\begin{array}{l}\text { - Complete trust between partners; } \\
\text { - Commitment to joint work and adoption of strategies that lead to world-class } \\
\text { performance; } \\
\text { - Trust and information-sharing become routine; } \\
\text { - Suppliers become an extension of the purchasing company. }\end{array}$ \\
\hline
\end{tabular}

Source: Adapted from Monczka et al. (2002)

The concept of collaboration put forward by Spekman et al. (1998) suggests that effective management of the chain depends on the search for close, long-term relationships with a limited number of customers and suppliers, who depend on each other in order to do business, i.e., develop interactive relationships with partners who share information freely, work together to resolve problems, develop products, on joint planning for the future and for whom success means interdependence.

\subsection{Strategic Alignment}

From the previous discussion emerges the conclusion that collaborative, long-term relationships with business partners are a way of achieving stronger competitive positions to a increasing number of companies. However, according to Tamas (2000), there is a mismatch between supply chain processes and corporate strategic goals, a finding echoed by Mitra and Bhardwaj (2010).

The alignment of supply chain strategies with corporate and business strategies is considered to be essential for the overall success (Chopra and Meindl, 2007). Proper alignment can lead to successful business (Cox, 2004; Mitra and Bhardwaj, 2010).

A company's supply chain strategy and competitive strategy must fit together (Cox, 2004; Cox et al, 2007; Chopra and Meindl, 2007). Competitive strategy is defined as the set of customer needs that a firm seeks to satisfy through its products and services; and supply chain strategy is defined as a determinant of the nature of logistics, purchasing and manufacture way of acting. Both strategies should have the same goals, in a concept called strategic fit by Chopra and Meindl (2007).

According to Christopher (2005), the nature of demand has a direct impact in the characteristics of business strategies, since predictable supply and demand suggests a better fit with a highly efficient supply chain strategy; on the other hand, highly uncertain supply and demand suggests a better fit with a highly responsive supply chain strategy.

To achieve the strategic fit, a company must ensure that its supply chain capabilities support its ability to satisfy the targeted customer segments (Cousins, 2005; Mitra and Bhardwaj, 2010).

Several authors (Vachon et al, 2009; Cox, 2004; Cox et al, 2007) refer to strategic fit as a compatibility issue between customer priorities and the ability of the supply chain in satisfying those priorities. Hence, all the resources available in the supply chain need to be managed according to the concept of strategic fit, in order to succeed in dynamics business environment. A company can fail in succeed not only by strategic misalignment, but also by poor management of resources and business process.

Such assertions are corroborated by Fisher (1997), which stated that the way of managing supply 
chains should have a single strategy of action, coinciding with the characteristics of products, which are functional or innovative. Functional products, whose demand is predictable and the life cycle long, point to lean supply chains, guided by efficiency in their processes. The innovative products, characterized by less predictable demands and shorter life cycles, suggest the need for supply chains which are more flexible in the product mix, volumes and delivery (Van de Vaart and Van Donk, 2006).

So, come into play such concepts as efficiency - the ability to operate in a leaner way, with lower consumption of resources - or responsiveness - ability to respond expeditiously to market movements (Vachon et al, 2009), operating with superior performance in matters such as speed, flexibility and reliability, responding quickly to market movements. Supply chains driven by market needs should be formatted and managed in a single strategy backed up somewhere along the spectrum between extreme efficiency or responsiveness (Chopra and Meindl, 2003; Christopher, 2005). This way you can achieve the strategic alignment of the supply chain. For Chopra and Meindl (2003), expanding the scope of strategic alignment along the network is a way to improve the competitive performance of the entire supply chain.

The scope of strategic alignment appears in a gradual way (Lee, 2004). For this author, it starts when there is alignment of information on demand forecast and production plans. After these initial steps, it intensifies when there is alignment of definition to the role and responsibilities of each member of the supply chain. Finally, the final step is the alignment of incentives so that the maximization of returns conducive to maximizing the performance of the supply chain.

\subsection{Hypotheses}

Inspired by supply chain management and strategic alignment literature, the current study tests the following two hypotheses, in the context of Brazilian automotive companies - automakers and first tier suppliers.

H1. The first tier suppliers align their supply practices with the practices considered valuable to their main customers.

Several studies show that the established time-based competition in the auto industry has led automak- ers to establish collaborative ties with their suppliers (Hines, 1998, Dyer and Chu, 2000; Zirpoli and Caputo, 2002; Liker and Choi, 2004; Choi and $\mathrm{Wu}, 2009$ ). An example is the implementation of belts or parks for suppliers, whose geographical proximity to automakers facilitates the synchronization of logistics processes of both and reducing costs resulting from these processes (Pfohl and Gareis, 2005).

There are different reasons why suppliers and customers in the automotive industry are stepping up their bonds - in some cases, reaching a total dedication to customer. One may be a maker's supply decision based on strategy of single sourcing for the item or category of material, usually with interest in consolidated volumes and ensure coordination between the activities performed (Gadde and Hakannsson, 2001). Another reason is to create supplier belts when companies in the first layer are requested by the client to establish a subsidiary or even move to a physical location close to the automaker's plant - sometimes attached to this plant (Correa, 2001). The goal, in these two cases is coincidental: create the conditions to lead to an advanced integration between the activities of both companies, especially operational processes and logistics, increasing the level of service provided by the customer.

It is assumed that strengthened links contribute to a greater alignment of practices in supply chains (Chopra and Meindl, 2007). From this statement comes the second hypothesis:

$\mathrm{H} 2$ : Supply practices of companies with stronger links to their customer are aligned to the supply practices adopted by their main customers.

Lower misalignment is to be expected in situations where there is a very strong link between automakers and direct suppliers (Barbieri and Mahapatra, 2009), creating dependence from supplier to the automaker. In those relationships, the automakers tend to coordinate its supplier activities.

\section{RESEARCH METHODOLOGY}

This study was carried out according to criteria put forward by Collis and Hussey (2009) and it makes an exploratory-descriptive study of objectives, using quantitative/qualitative procedures and inductive reasoning.

According to Malhotra (2001) exploratory-descriptive research is recommended when the research 
seeks to describe the characteristics of any phenomenon, assess the behavior of a specific population or confirm the relationship between variables. According to Creswell (2007), quali-quantitative research combines techniques and methods from the field such as observation and interviews with traditional studies using quantitative data. Inductive logic is used as the method of reasoning about the topic, with the aim of not only producing ideas but of also guiding reflection about them (Malhotra, 2001). The methodological procedure, using multi-case studies, normally involves in-depth and detailed analysis of the object of research.

\subsection{Data}

Non-probability sampling according to accessibility was used to obtain the sample. This sampling method was chosen because of the difficulty in obtaining access to the companies studied. Collis and Hussey (2009) confirm that it is sometimes difficult to obtain a sample, especially when dealing with sensitive or confidential matters.

The target population of this research consisted of the first tier suppliers of automobile automakers. The membership list of SINDIPEÇAS - National Association of Automobile Components Manufacturers - was used to carry out the company survey. In total, 35 companies were visited. As a result of the strategy for optimizing the supplier base used by the Brazilian automotive industry, which has led to a pronounced reduction in the number of first tier suppliers, due to the practices involved in modularization of production (Correa, 2001; Venanzi and Gobbo Júnior, 2009), it is reasonable to assume that the companies included in the sample are important actors on the Brazilian automotive scene.

The units of observation were the purchasing managers or those responsible for this area, working for first tier suppliers and taking direct part in the management of the second tier supplier base and the relationship established with it.

\subsection{Research Strategies and Type of Information}

Data collection was carried out in loco (on site) by means of interviews using semi-structured questionnaires. The following categories of questions were used: a) identification of - company type; b) identification of the three main automakers serviced; c) identification of the three most important materials purchased d) assessment of the importance of the ten performance criteria in selecting and evaluating second tier suppliers; e) assessment of the same performance criteria from the standpoint of each of the three automakers supplied by the company under study.

\subsection{Analytical Models used in the Research}

The concept used for analyzing the alignment of practices was taken from Vachon et al. (2009), and proposes that the degree of misalignment corresponds to the strength of the gaps between the customer's needs and the importance given to these needs by the first tier supplier in dealings with second tier suppliers. This concept was used in the automotive industry and has produced satisfactory results (Martins et al., 2010).

The strategic misalignment for each automaker-supplier pair is obtained by totaling the absolute values of the difference, in percent, between the importance of each criterion used by the first tier supplier in order to evaluate second tier suppliers and the importance of these same criteria for the automakers in their relationship with first tier suppliers in the opinion of the latter. The higher the figure obtained, the more misaligned the first tier supplier's strategy is with the strategy of the automaker. The formula for this calculation is:

$$
A_{y}=\sum_{n=1}^{10}(|C D F-C D C| \div C D C)
$$

where:

$A_{y}=$ strategic misalignment for the automaker - supplier pair $y$;

$n=$ performance criterion;

$\mathrm{CDF}=$ importance of the performance criterion in relationship with the second tier supplier

$\mathrm{CDC}=$ importance of the performance criterion from the point of view of the customer in its relationship with the first tier supplier.

Strategic misalignment was assessed on the basis of the total amount of individual misalignment calculated for each automaker - supplier pair according to the formula presented in (1). 
The method for analyzing strategic misalignment used the marks awarded by respondents as input and consisted of two stages. In the first stage 10 performance criteria for the automotive sector were selected from Hines (1998), Dyer and Chu (2000) and Ogden (2006). The criteria were as follows: support for projects of new products development, punctuality, rapid cycle time, price, production capacity, quality, sharing of information about production plans, sharing information regarding costs, flexibility and financial structure. The respondents were asked to rank these criteria from 1 to 10 according to their importance in the processes of selecting and evaluating second tier suppliers, where 10 was awarded to the most important criteria and 1 for the least important.

In the second stage, as a way of ensuring that the analysis of the practices adopted in relationship with second tier suppliers only included those who were significant for the first tier supplier's business, respondents were requested to identify the three most important materials purchased. From this point onwards, responses only considered the suppliers of each one of these items. The criterion used for importance was the annual spent on the item.

The same respondents were also asked to use the same procedure in deciding on the importance of the ten performance criteria but this time from according to the opinion of each of the three main automakers served by the company. This procedure was intended to obtain the suppliers' opinion of the performance requirements demanded by the automakers.
The strength of the link is a construct that was determined by the percentage of sales revenue received from the main automaker serviced by the first tier supplier. For the segmentation, the suppliers were divided into two groups: suppliers that had a very strong link with their main automaker and suppliers with links spread among different automakers. Analysis of the data led to the conclusion that the figure of $40 \%$ of sales revenue formed the dividing line between the two groups. In addition to constituting a significant percentage of the supplier's sales, it was found that approximately the same numbers of companies were to be found in the two groups - 16 in the first and 15 in the second. Another four companies did not provide information about the sales revenue received from their main customer and their questionnaires were excluded from the research.

Lower misalignment is to be expected in situations where there is a very strong link between automakers and direct suppliers (Barbieri and Mahapatra, 2009). According to the authors, an automaker tends to exercise its power of leadership in pursuit of its competitive priorities in the clearest manner in situations where a supplier's dependence is most obvious, and, therefore, even if indirectly, coordinating its suppliers activities in one way or another. In acting this way, they certainly influence suppliers' practices in such a way that they tend to replicate upstream the perceptions acquired downstream.

Figure 2 shows the model used for analysis of the first segmentation.

Figure 2. Model used to analyze Strategic Misalignment, according to the Type of Link between Automakers and First Tier Suppliers

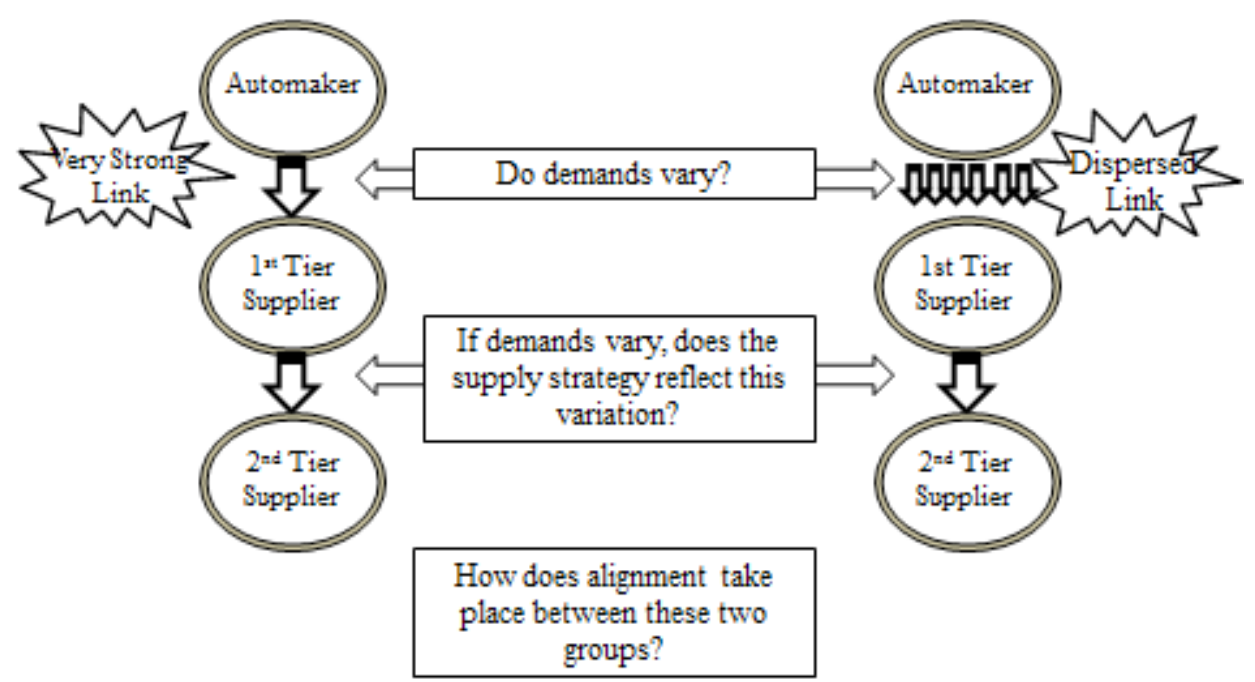




\section{STATISTICAL RESULTS}

The results obtained are presented in segments according to the strength of links. At the end there is a discussion of the implications of the results for the effectiveness and performance of supply chains as a result of type of alignment.

\subsection{Characteristics of the sample}

First, it is important to present several additional relevant characteristics of the sample. Table 1 shows average results for: number of employees per plant; annual revenue; annual spending on procurement as a percentage of revenue; number of suppliers that account $80 \%$ of annual spending on procurement of direct materials; and number of active suppliers for each direct material.

Table 1. Characteristics of the sample

\begin{tabular}{lc}
\hline \multicolumn{1}{c}{ Characteristics } & Average \\
\hline Number of employees per plant & 602,1 \\
Annual revenue (in Brazilian Reais) & 227,1 \\
Annual spending on procurement (in \% of revenue) & 57,60 \\
Number of suppliers that account 80\% of annual & 2,7 \\
spending in direct materials & 3 \\
Number of active suppliers for each direct material & \\
\hline
\end{tabular}

It can be confirmed that, in general, the companies analyzed have high rates of outsourcing, since the percentage of sales revenue assigned to purchases from suppliers is close to $60 \%$. This percentage is close to the average for automakers in the rest of the world (Monczka et al., 2002).

\subsection{Analysis of the Materials purchased}

Figure 3 presents the materials that are acquired from three major's suppliers of the studied companies. The objective of the analysis of this data is to verify which type of materials are purchased and if there are different levels of complexity among these materials. Accordingly to Ellram (1992), the level of complexity of the products involved in the act of buying and selling determines the required type of coordination between the companies involved.

Figure 3. Occurrences of the three most important materials acquired by the companies

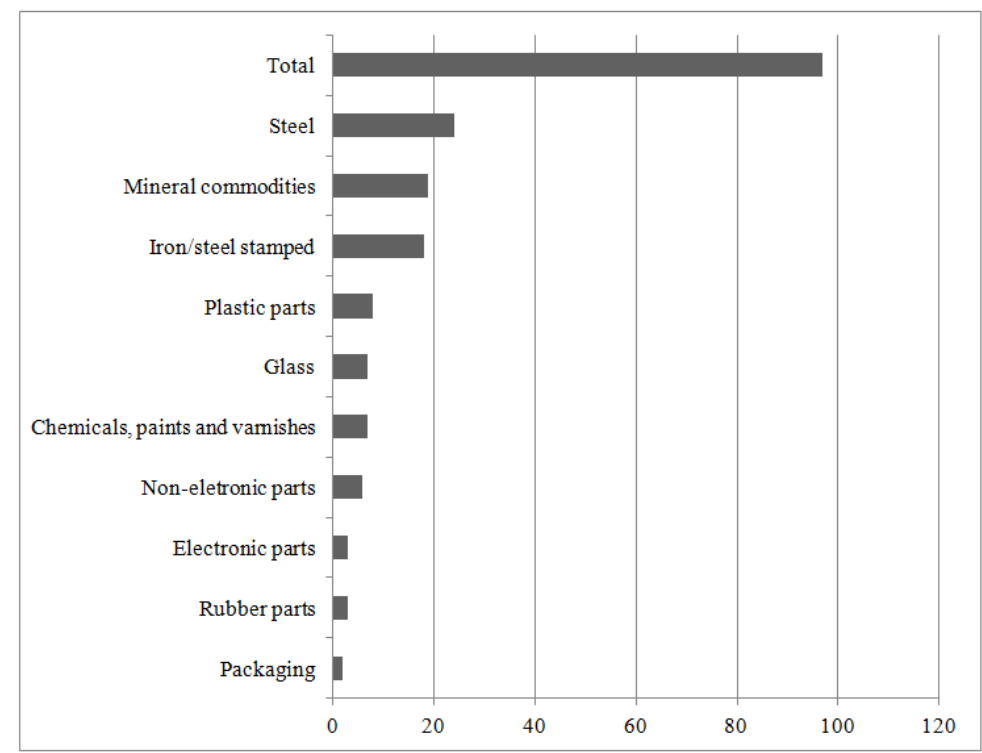


From the information presented in Figure 3, it was verified the prevailing incidence of low technological complexity materials such as steel, steel and iron stamped parts, mineral commodities, plastic parts, glass, paints, varnishes, rubber parts and packaging.

Therefore, it can be assumed that the different type of materials purchased by the companies does not influence in the priority performance criteria. The type of coordination needed to manage the relationships with these suppliers is reasonably equivalent, bringing consistency to the type of practice adopted, at least from the point of view of the complexity of the materials involved in the transactions.

\subsection{Analysis of the misalignments based on the rela- tive importance of performance criteria}

The research procedures included carrying out an analysis of the average values for importance given to the ten performance criteria presented by the first tier suppliers in Section 3.3. At this point, it is important to remember that the results for the importance given to the performance criteria are relatives, since the respondents were asked to ranking them in a 1 to 10 scale, without the possibility of attributing the same level of importance to different performance criteria.

The misalignment was calculated according to formula (1) presented before. Data obtained from the 31 valid questionnaires generated 68 pairs of analysis. Since each respondent was asked to attribute relative importance for the ten performance criteria considering the three main customers, a total of 93 evaluations were expected. However, 3 companies evaluated the criteria considering only the two main customers, since they represent almost the totality of the sales. For the same reason, 11 companies considered only one main customer in the evaluation. Consequently, the result is 68 pairs of supplier-customer evaluations of importance of criteria performance. Table 2 presents the distribution of the calculated misalignment categorized in four levels. Considering the formula (1), the range of misalignment varies from zero to about 18 .

Table 2. Results of calculated misalignment categorized in levels of intensity

\begin{tabular}{lc}
\hline \multicolumn{1}{c}{ Intervals of misalignment } & Cases \\
\hline $0-4,0$ & 36 \\
$4,1-8,0$ & 22 \\
$8,1-12,0$ & 10 \\
$>12,01$ & 0 \\
\hline
\end{tabular}

In order to represent the existence or not of misalignment, and to meet the chi-square test requirements, the authors decided to synthesize data in two classes, namely low to none misalignment and medium to high misalignment - Table 3 - and score eight for misalignment was chosen as the dividing line between the two classes.

Table 3. Frequency distribution of misalignment

\begin{tabular}{lcc}
\hline $\begin{array}{r}\text { Categories of } \\
\text { misalingment }\end{array}$ & Frequency & \% of total \\
\hline Low to none & 58 & $85,3 \%$ \\
Medium to high & 10 & $14,7 \%$ \\
\hline
\end{tabular}

In practice, the number of classes and its approximate amplitude are determined by trial and error, and the analyst should use judgment to determine the combination that provides the best means to synthesize the data (Anderson et al, 2005).

Table 4 summarizes the results of chi-square tests on these data, and the results presented in it help to address Hypothesis 1. Left to chance, one would expect the predominance of low to no misalignment category, in a proportion of $70 \%$ to $30 \%$ to the other category, in order to confirm H1. The authors chose expected proportion as the one that indicates evidence of the predomination of the first category over the second one. If the choice was $50 \%$ to $50 \%$ for both categories, or even $60 \%$ to $40 \%$, respectively, the interpretation of the results would rest inconclusive, since it is necessary a strong predominance of the first category over the second one to allow the authors to state conclusions over the test of hypotheses. The Chi-square test of a multinomial experiment suggests there is no difference between the predicted and actual proportions of misalignment categories $(p=0.05)$. The chi-square test usually requires a number equal or above 10 responses in each individual cell to be valid, a condition that was satisfied in these data (Anderson et al, 2005).

Table 4. Chi-square test for misalignment distribution

\begin{tabular}{ccc}
\hline Categories & $\begin{array}{c}\text { Predicted } \\
\text { proportion }\end{array}$ & $\begin{array}{c}\text { Actual } \\
\text { proportion }\end{array}$ \\
\hline Low to none & $70 \%$ & $85,3 \%$ \\
Medium to high & $30 \%$ & $14,7 \%$ \\
$\mathrm{X}^{2} 0,00084161$ not & & \\
significant at $\mathrm{p}=0,05 ; \mathrm{n}=68$ & & \\
\hline
\end{tabular}


The result suggests the inexistence of difference between the expected frequency distribution and the observed one. In conclusion, its possible to state that misalignment in these data is low or inexistent in most cases, giving support to the assessment presented in hypothesis 1 - the companies interviewed align their supply practices with the practices considered valuable to their main customers.

Another way of presenting the results is to plot in a chart the average result for the evaluation of importance of each performance criteria, considering the suppliers evaluation and the perception of customer evaluation-Figure 4.

Figure 4. Average of importance attributed for each performance criteria by suppliers and their perception of importance assigned to them by customers

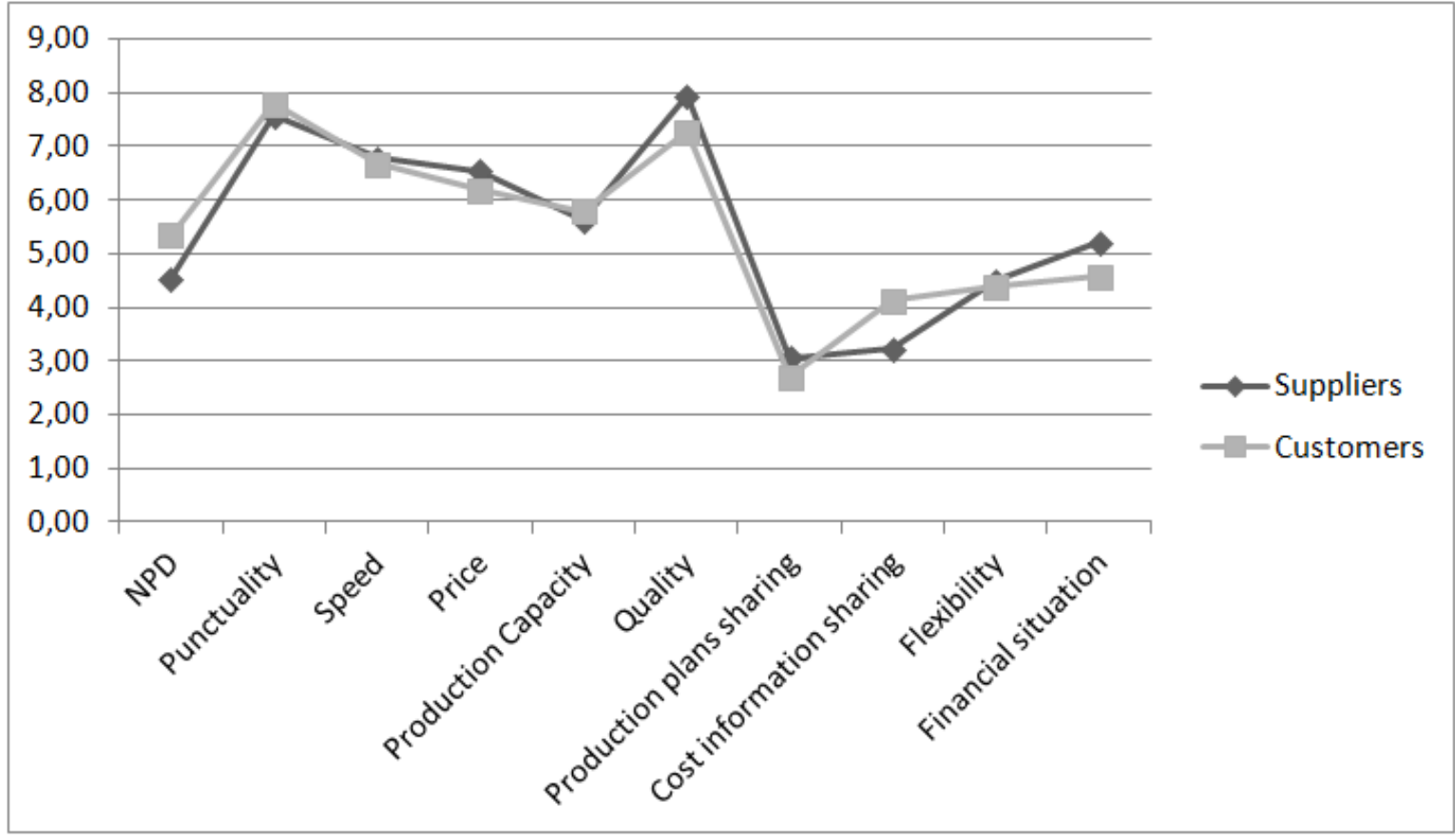

From this figure is possible to identify what seems to be a concordance in both evaluation to the importance of performance criteria, which would be interpreted as an indication of low level of misalignment in the practices in those supply chains.

In Brazil, an important transformation of the automotive sector was the concentrated and intense process of internationalization of the participating companies (Salerno et al., 2002) which led to increased competition, creating a race for the renovation of production plants. This process also resulted in new management practices of internal processes and supply chain (Aguiar, 2001; Salerno et al., 2002, Lima, 2004; Bronzo et al., 2005), in a new setting for the Brazilian automotive chain, with the adoption of a horizontal model based on modular production.

The main result of these changes was the approximation between the assemblers and first-tier suppliers, developing a new type of relationship that requires information sharing and collaboration among companies from the perspective of a single chain project (Monczka et al., 2002).

The discussion related to the low or none misalignment found in these pairs of automakers and suppliers seems to corroborate such transformation in the relationships in the Brazilian automotive supply chain, towards a single chain project. According to Fisher (1997), the way of managing supply chains should have a single strategy of action, coinciding with the characteristics of products. According to the results, it seems that the first tier suppliers manage relationships with the second tier in a way that express similarity with what is considered important by automakers.

\subsection{Analysis of the relationship between misalign- ment and intensity of link}


In order to test the second hypothesis, an analysis of the relationship between misalignment and intensity of the link will be carried out. The information needed for the latter was obtained from a question of the survey instrument that asked the respondent to reveal the percentage that the top three customers accounted for company revenue. The strength of the link is a construct that was determined by the percentage of sales revenue received from the main automaker serviced by the first tier supplier. Such information expresses the intensity of the link for each pair automaker-supplier.

As a statistical technique, simple linear regression analysis will be used, in search of the determination of the correlation coefficient between the two proposed variables, with misalignment as dependent variable and intensity of the link as independent variable. The results are presented in Table 5.

Table 5. Result of Simple Linear Regression Analysis

SUMMARY OUTPUT

\section{Regression Statistics \\ Multiple R}

R Square

Adjusted R

Square

Standard Error

Observations

ANOVA

\begin{tabular}{|c|c|c|c|c|c|c|}
\hline & $D F$ & & SS & $M S$ & $F$ & $\begin{array}{l}\text { Significance } \\
F\end{array}$ \\
\hline Regression & & 1 & 42,02019 & 42,02019 & 4,073743 & 0,048829 \\
\hline Residual & & 51 & 526,0592 & 10,31489 & & \\
\hline Total & & 52 & 568,0794 & & & \\
\hline
\end{tabular}

\begin{tabular}{|c|c|c|c|c|c|c|c|c|}
\hline & Coefficients & $\begin{array}{c}\text { Standard } \\
\text { Error }\end{array}$ & $t$ Stat & P-value & Lower 95\% & $\begin{array}{c}\text { Upper } \\
95 \%\end{array}$ & $\begin{array}{c}\text { Lower } \\
95 \%\end{array}$ & $\begin{array}{c}\text { Upper } \\
95 \%\end{array}$ \\
\hline Intercept & 4,851243 & 0,727074 & 6,672287 & 0,0000002 & 3,391582 & 6,310905 & 3,391582 & 6,310905 \\
\hline Intensity of link & $-3,46702$ & 1,717747 & $-2,01835$ & 0,048829 & $-6,91554$ & $-0,0185$ & $-6,91554$ & $-0,0185$ \\
\hline
\end{tabular}

Table 5 presented above shows the results of the first regression analysis, with misalignment as the dependent variable and intensity of the link as the independent variable. The $\mathrm{R}$ square coefficient equivalent to 0,07 means that there is a weak relationship between misalignment and intensity of the link, since only $7 \%$ of the variation of the first can be attributed to variations in the second.

Using the F-test, it is possible to reject the null hypothesis that there isn't significance in the relationship between the variables analyzed. The F-value of 4.88 is greater than 4.08 , which comes to be the F value with $\alpha$ equal to 0,05 . However, the F-test is not sufficient to state that there is a relation of cause and effect between them.

Consequently, as a result of this analysis, it is not possible to confirm the second hypothesis for this group of companies, since one cannot say that there is a relationship of cause and effect between intensity of the link and misalignment of practices in those supply chains. In other words, it is possible to state that, for those supply chains, having dispersed links does not affect the misalignment of practices. 


\section{CONCLUSIONS}

The aim of this research was to study the companies making up the supply chains of the Brazilian automotive industry in order to identify misalignment in their supply strategies.

To this end, evidence was sought for the acceptance and implementation of practices in the relationship between automakers and their first tier suppliers as well as practices of the same type between these first tier suppliers and their (second tier) suppliers. Behind this investigation is the concept of strategic alignment - or strategic fit. A company's supply chain strategy and competitive strategy must fit together (Cox, 2004; Cox et al, 2007; Chopra and Meindl, 2007), meaning that the company must ensure that its supply chain capabilities support its ability to satisfy customer's needs (Cousins, 2005; Mitra and Bhardwaj, 2010).

The main conclusion of this study was that, for the analyzed sample of companies, there is evidence to confirm H1, which states that first tier supplier align their supply practices with the practices considered valuable to their main customers. That conclusion comes from the figure of the misalignment, calculated considering 68 pairs of relationship between the importance of each performance criteria in supply management and the perception of importance attributed to the same criteria by the three main customers.

In Brazil, an important transformation of the automotive sector was the concentrated and intense process of internationalization of the participating companies (Salerno et al., 2002), which led to increased competition, leading to the renovation of production plants. This process also resulted in new management practices of internal processes and supply chain (Salerno et al., 2002, Lima, 2004; Bronzo et al., 2005), in a new setting for the Brazilian automotive chain, with the adoption of a horizontal model based on modular production system.

The main result of these changes was the approximation between the automakers and first-tier suppliers, developing a new type of relationship that requires information sharing and collaboration among companies, from the perspective of a single chain project (Monczka et al., 2002). The result of the hypothesis testing seems to corroborate that assumption.

A subsidiary conclusion from the study was that the presence of a very strong link between supplier and customer did not produce a lower degree of strategic misalignment in the supply chains. That comes from the rejection of the second hypothesis, which stated that supply practices of companies with stronger links to their customers are aligned to the supply practices adopted by their main customers.

There are different reasons for first tier suppliers and automakers to strengthen their links: (i) to establish a single sourcing policy in order to stabilize sales and ensure that activities are coordinated; (ii) to lead suppliers to locate themselves in zones around the automaker with first tier suppliers sitting themselves near the automakers. In both cases, the aim is to lay the foundations for the integration of each company's activities, especially operational and logistic processes (Salerno et al., 2002; Marini et al., 2004). Initiatives to organize supply networks with strong links are taken by automakers, mainly in order to reduce costs and increase flexibility (Venanzi and Gobbo Júnior, 2009).

The data collected and presented above show that there is a weak relationship between misalignment and intensity of the links, since only $7 \%$ of the variation of the first can be attributed to variations in the second.

The subsidiary conclusion placed in an isolated condition may lose its managerial importance, since the main conclusion of the study stated that the analysis of the whole sample points to the existence of low to none misalignment of practices. In other words, even for the companies with dispersed links, it seems that the supply practices are not misaligned between the tiers, a phenomena that the literature consider a desirable one (Vachon et al, 2009; Cox, 2004; Cox et al, 2007).

It must be emphasized that these results should be interpreted according to the limitations of the research. Perhaps the primary limitation of the current study is its exclusion of deeper analysis of the scope of strategic alignment, since Lee (2004) state that it can be gradual. Hence, seems to be necessary an evolution on the model of the research, in order to better explain the intrinsic quality of the strategic fit.

Although the model used has already been tested in studies carried out in other countries, the results obtained may be distorted by the fact that they reflect perceptions from one single tier of the supply chain. In contrast, chains where assets are highly specific, for example, trucks and agricultural equipment, or where a strong cultural element is present, as in the 
case of recently arrived Asian automakers, or when companies decide to engage in manufacture far from the customary geographical locations, such as the states of Bahia and Goiás, may behave in a significantly different manner than those studied in this research. Still, the use of nonprobability sampling techniques suggests the existence of restrictions to infer from the sample to the general population.

This paper makes a contribution from both the academic and management point of view. One of these contributions is an analysis of the relationship established in tiers that are the furthest removed from the most important companies, an area that has so far received little empirical study. Another important contribution to management studies is the identification of practices that support the expansion of a new model of arrangements adopted by automotive companies in Brazil. In addition, this research helps to understand the processes automotive companies have adopted to manage their supply operations and the implications of these activities for the competitiveness of those companies and their supply chains.

This study suggests some possible topics for future research. One of the opportunities refers to the possibility of analyzing the influence exercised by the type of product sold, especially its level of technological complexity, on the practices described in the present study. Another possibility concerns the study of changes in supply practices as a result of the use of information technology improving information flow in the supply chain.

\section{REFERENCES}

Ambrose, E.; Marshall, D.; Lynch, D. (2010) Buyer Supplier Perspectives on Supply Chain Relationships. International Journal of Operations \& Production Management. Vol. 30, n.12.

Anderson, D.R.; Sweeney, D.J.; Williams, T.A. (2005) Estatística Aplicada à Administração e Economia. São Paulo: Pioneira Thomson Learning.

ANFAVEA. National Association of Automotive Vehicle Manufacturers (2010). São Paulo, 2010. http://www.anfavea.com. br/anuario.html. Acessed in 09/01/2010.

Barbieri, P. and Mahapatra, S. (2009), “Buyer-supplier relationship in supply network: implications of tier-II supplier management practices", Proceedings of the 2009 European Operation Management Association Conference, Götenburg.

Barratt, M. and Oliveira, A. (2001), “Exploring the experiences of collaboration planning initiatives", International Journal of Physical Distribution e Logistics Management, Vol. 31 No. 4, pp. 266-289.
Bronzo, M.; Arruda, R.; Takahashi, B.; Eder, L. M. (2005) “Organização da função logística dos grandes contratantes da cadeia de suprimentos da Fiat Automóveis do Brasil". In: XXIX Encontro da ANPAD, 2005, Brasília. Anais do....

Carr, A. S.; Pearson, J. N. (2002) The Impact of Purchasing and Supplier Involvement on Strategic Purchasing and its Impact on Firm's Performance. International Journal of Operations $\mathcal{E}$ Production Management. v. 22, n. 9.

Choi, T. Y. and Wu, Z. (2009), “Triads in supply networks: Theorizing buyer-supplier- relationships", Journal of Supply Chain Management, Vol. 45 No. 1, pp. 8-25.

Chopra, S. and Meindl, P. (2007), Supply Chain Management: Strategy, Planning, and Operation. $3^{\text {rd }}$ ed., Upper Saddle River, New Jersey: Pearson Education, Inc..

Christopher, M. (2005) Logistics \& Supply Chain Management: Creating Value-Adding Networks. $3^{\text {rd }}$ Edition, London, UK: FT Press.

Collis, J.; Hussey, R. (2009), Business research: a Practical Guide for Undergraduate and Postgraduate Students, $3^{\text {rd }}$ Edition, Basingstoke: Palgrave Macmillan.

Correa, L. H. (2001), “The VW Resende (Brazil) plant modular consortium SCM model after 5 years of operation", Proceedings of the 2001 Annual Conference of the Production and Operations Management Society, Orlando.

Cousins, P. (2005) “The alignment of appropriate firm and supply strategies for competitive advantage". International Journal of Operations \& Production Management; Vol. 25 Issue 5, p403-428,

Cox, A. (2004) "Business relationship alignment: on the commensurability of value capture and mutuality in buyer and supplier exchange". Supply Chain Management: An International Journal. Volume: 9 Issue: 5

Cox, A.; Chicksand, D.; Yang, T. (2007) “The proactive alignment of sourcing with marketing and branding strategies: a food service case". Supply Chain Management: An International Journal. Volume: 12 Issue: 5

Creswell, J.W. (2003), Research Design: Qualitative \& Quantitative, and Mixed Methods Approaches, $2^{\text {nd }}$ Edition, Thousand Oaks, CA: Sage.

Croxton, K.L.; García-Dastugue, S.J.; Lambert, D.M.;Rogers,D.S. (2001) "The supply chain management processes. The International Journal of Logistics Management", v.12, n.2. p.13-36

Di Serio, L. C., Sampaio, M., Pereira, S.C.F. and Moreira, M. A. S. (2005), "Supply chain design in the Brazilian automotive industry", Proceedings of the 20051 Annual Conference of the Production and Operations Management Society, 2005, Chicago.

Dyer, J. and Chu, W. (2000), “The determinants of trust in supplier-automaker relationships in the US, Japan and Korea", Journal of International Business Studies. Vol.31 No.2, pp. 259-285.

Ellram, L. (1992), "Partners in international alliances", Journal of Business Logistics, Vol. 13, pp. 1-25.

Fischmann, E. (2007), O papel da engenharia local dos fornecedores de autopeças e a integração com as montadoras no desenvolvimento de novos produtos. São Paulo, 2007. Dis- 
sertation (Master degree - Engineering). Escola Politécnica da Universidade de São Paulo.

Fisher, M.L. (1997) "What is the Right Supply Chain for your Product". Harvard Business Review. Vol. 75, n.2.

Ford, D.; Gadde, L.E.; Håkansson, H.; Snehota, I. (2003) Managing Business Relationships. 2a ed. Chiscester, Inglaterra: John Wiley \& Sons Ltd., 215 p

Gadde, L.E.; Hakansson, H. (2001), Supply Network Strategies. Chichester: John Wiley \& Sons.

Godsell, J.; Birtwistle, A.; van Hoek, R. (2010) “Building the supply chain to enable business alignment: lessons from British American Tobacco (BAT)". Supply Chain Management: an International Journal; Vol. 15 Issue 1, p10-15.

González-Benito, J. (2010), “Supply strategy and business performance", International Journal of Operations \& Production Management, Vol. 30 No. 8, pp. 774-797.

Hair, J.F., Anderson, R.E., Tatham, R.L. and Black, W.C. (2005), Multivariate Data Analysis, Upper Saddle River, NJ: Prentice Hall.

Håkansson, H.; Snehota, I. (1995) Developing Relationships in Business Networks. Routledge, London.

Hines, P. (1995), "Network sourcing: a hybrid approach", International Journal of Purchasing and Materials Management, Vol. 31 No. 2,pp. 17-24, March.

Lambert, D. M.; Cooper, M. C.; Pagh, J. D. (1998) Supply chain management: implementation issues and research opportunities. International Journal of Logistics Management. v. 9, n 2, p. 1-19.

Lee, H. L. (2004) “The Triple-A Supply Chain”. Harvard Business Review. Vol 82, n.10.

Liker, J.K. and Choi, T.Y. (2004), “Building deep supplier relationships", Harvard Business Review, Vol. 82 No. 12, pp. 104-113.

Lima, J. (2004) Um estudo sobre a reconfiguração da função compras em empresas do setor automotivo. Universidade de São Paulo, São Paulo.

Malhotra, N.K. (2001), Marketing Research: An Applied Orientation, Upper Saddlle River, NJ: Prentice Hall.

Marini, M.L.; Gonçalves, M.B. and Giacobo, F. (2004), “O Relacionamento e as Novas Configurações entre Montadoras de Automóveis e seus Fornecedores", Proceedings of the 2004 SEMEAD - Seminários em Administração FEA-USP, São Paulo.

Martins, R.S.; Souza Filho, O. V. and Pereira, S.C.F. (2010), “Collaboration in the Brazilian automotive chain: Are there strategic alignment in this industry?", Proceedings of the 2010 European Operation Management Association Conference, Porto.

Mitra, A,; Bhardwaj, S. (2010) "Alignment of Supply Chain Strategy with Business Strategy". The IUP Journal of Supply Chain Management. Vol. VII, N. 3, 2010.
Monczka, R., Trent, R. and Handfield, R. (2002), Purchasing and Supply Chain Management, $2^{\text {th }}$ Ed. Cincinnati: Thomson Learning.

Ogden, J.A. (2006), "Supply base reduction: an empirical study of critical success factors", Journal of Supply Chain Management. Vol. 42 No. 4, pp. 30-40.

Paulraj, A.; Chen, I.J.; Flynn, J. (2006) Levels of Strategic Purchasing: Impact on Supply Integration and Performance. Journal of Purchasing and Supply Management. Vol. 12.

Pfohl, H. C.; Gareis, K. (2005) "Supplier Parks in the German Automotive Industry". International Journal of Physical Distribution \& Logistics Management. Vol. 35, n. 5.

Salerno, M.S.S., Marx, R. and Zilbovicius, M. (2010), A Nova Configuração da Cadeia Automotiva no Brasil: Rumo a um Pólo de Excelência em Projeto e Produção? Relatório Técnico (projeto para o BNDES). Departamento de Engenharia de Produção - Escola Politécnica da Universidade de São Paulo, 2002. Disponível em < http://www.poli.usp.br/pro/cadeiaautomotiva $>$.Acesso em: 12 Agosto 2010.

Skjoett-Larsen, T. (1999), “Supply Chain Management: a new challenge for researchers and managers in Logistics", International Journal of Logistics Management, Vol. 10 No. 2, pp. 41-53.

Spekman, R. et al. (1998), "An Empirical investigation into Supply Chain Management: a perspective on partnerships", International Journal of Physical Distribution \& Logistics Management. V. 28 No. 8, pp. 630-650.

Tamas, M. (2000), "Mismatched strategies: the weak link in the supply chain?", Supply Chain Management, Vol. 5 No. 4, p. 171

Vachon, S., Halley, A. and Beaulieu, M. (2009), "Aligning competitive priorities in the supply chain: the role of interactions with suppliers", International Journal of Operations \& Production Management. V. 29 No. 4, pp. 322-344.

Van der Vaart, T.; Van Donk, D. P. (2006) “Buyer-focused Operations as a Supply Chain Strategy". International Journal of Operations E Production Management. Vol. 26, n. 1.

Venanzi, D. and Gobbo Júnior, J.A. (2009), "A Study of new production models from an operations strategy perspective: the case of modular consortium (MC) and industrial condominium (IC) in Brazil's automotive industry", Proceedings of the 2009 European Operation Management Association Conference, Götenburg.

Zheng, J.; Knight, L.; Harland, C.; Humby, S.; James K. (2007) An Analysis of Research into the Future of Purchasing and Supply Management. Journal of Purchasing \& Supply Management. Vol. 13.

Zirpoli, F.; Caputo, M. (2002) “The Nature of Buyer-Supplier Relationships in Co-design Activities: The Italian Auto Industry Case". International Journal of Operations \& Production Management. Vol. 22, n. 12. 


\section{AUTHOR'S BIOGRAPHY}

Ricardo Silveira Martins - Doctor in Applied Economics from the University of São Paulo. Lecturer at UFMG. Teaches and carries out research in Operations and Logistics Management at the Post-Graduate Centre for Research in Management. One of the leaders of the Interdisciplinary Centre for Research in Logistics. Areas of activity: Supply Chain Logistics, Logistics in Small and Medium-sized Companies and Logistic Strategies.

Osmar Vieira Souza Filho - Visiting Lecturer of Supply Management at Dom Cabral Foundation. Researcher at Nipe-LOG - Interdisciplinary Research and Extension Center in Logistics in the Department of Business Administration, UFMG. Master in Business Administration from CEPEAD-UFMG, with specialization in Logistics and Supply Chain Management. Research interests: Purchasing and Supply Management.

Susana Carla Farias Pereira - Doctor in Management from the FGV-EAESP. Master of Science in Management from the University of Birmingham, UK. Associate Professor at FGV-EAESP; Scientific Coordinator of SIMPOI; Assistant in Pedagogic Processes at the Centre for Development of Teaching and Learning at FGVEAESP; Member of the Editorial Board of JOSCM; Researcher at the GMRG. Research interests: Operations Strategy and SCM.

Luiz Carlos Di Serio - Graduated in Mechanical Engineering at the State University of São Paulo (UNESP). Master in Mechanical Engineering, with specialization in Industrial Engineering, at Marquette University in Milwaukee, Wisconsin, USA. Has a doctorate in Mechanical Engineering, with specialization in Operations Management from the University of São Paulo (USP). Research interest: SCM, Competitiveness and Innovation. 